\title{
EDITORIAL OPEN A look at food security in China
}

npj Science of Food (2018)2:4; doi:10.1038/

s41538-018-0012-x

Who will feed China? This important question was raised by Dr. Lester R. Brown in his famous book by the same title. ${ }^{1}$ It is still a valid question today as food security continues to be one of the highest priorities for this most populated country in the world. Food production (namely, grain), inputs (fertilizer, water) and outputs (state of environment) are vital elements to a sustainable food system that must be considered along with consumers (people, animals) and where consumers are located (urban, rural). In the past century, China experienced numerous food shortages, then corrected them by implementing a quota system (1955-1993) and land contract reform (1981) that incentivized farmers. Total grain output increased 74\% from 354 million tons in 1982 to 618 million tons in 2017, surpassing the growth of its population by about $34 \%$. $^{2,3}$

Today, China feeds $20 \%$ of the world's population on $7 \%$ of the world's farmlands. ${ }^{2,3}$ To accomplish this feat, China paid a heavy price. China's excessive and inefficient use of chemical fertilizers, increasing 3-fold in the past three decades, efficiencies averaging at $32 \%$ compared to world average of $55 \%,{ }^{2}$ contributed to its current harmful state of environmental pollution.

Similarly, China's water situation is problematic with low efficiency, poor quality and unequal distribution throughout the country. China's available water supply per person is only $2050 \mathrm{~m}^{3}$ or $25 \%$ of the world's per capita average. Irrigation of rural crops accounts for $60 \%$ of China's total water demand with inefficient delivery of the order of $30-40 \%$, compared to $70-80 \%$ for developed countries. In some regions of northern China, where water is scarce, excessive amounts of groundwater are being directed to agriculture. Therefore, it is urgent that China proactively consider how to achieve food security through a balance of resource management, environmental protection and sustainable agricultural development.

In the future, improvement in grain productivity will depend more on technology adaptation than increasing resource inputs. China is making positive improvements to the quality of its soil, and to reducing its water and fertilizer use on crops. An accelerating rate of land transfers is leading to the construction of huge, modern farms with large scale planting and mechanization should further improve agricultural production efficiency. Advances in digital technologies can enable precision agricultural practices to increase grain production on the order of $10 \%$. Moreover, if genetically modified crops (GM-corn and GMsoybean) are permitted to grow in China, then they could ensure adequate grain production and supply with more efficient use of natural resources, while at the same time, moderating the use levels of agricultural chemicals, thus, reducing environmental pollution.

Among the three major cereal crops grown in China, the selfsufficiency ratio of wheat, rice and corn is about $95 \%$. In contrast, about $80 \%$ of consumed soybean and other agriproducts, such as milk and sugar, are imported to China. It is interesting that soybean imports significantly increased from 0.3 million tons in 1995 to 95 million tons in 2017, presently accounting for two-thirds of the world's soybean market. The per unit area yield of soybean is much less than that of other major crops, about $1 / 3$ of wheat, $1 / 4$ of rice and $1 / 5$ of corn. With China's shift to importing rather than growing soybean, a total of 50 million hectares of fertile cropland ( $40 \%$ of China's total arable land ${ }^{-} 120$ million hectares $^{1}$ ) freed up for growing other higher yielding crops.

A critical question is "How much grain will Chinese consumers require in the future?" The answer depends on China's population growth and its concomitant food demands. In 1980 when the government established the "one child policy"; it based population growth on models that predicted the birthrate would fall (from above 1.8 before 2000) and predicted a population of 1.6 billion in China by $20500^{4,5}$ It now seems that this prediction was greatly flawed and the total birthrate has been no more than 1.4. Thus, China's population was only 1.37 billion at the end of 2016 . A peak in China's population growth is now expected by 2025 with a total population of about 1.42 billion and then India is expected to replace China as the world's most populated country. ${ }^{6}$ After 2025, China's population is expected to decline rapidly and may fall to 1.2 billion by 2050 , and even further to 0.6 billion by $2100 .^{7}$

Severe problems due to the evolving Chinese aging population and low birth rate may soon arise, even with the "one child policy" being repealed in 2015. Families can now have a second child but many choose not to, because they cannot afford the high cost of raising children. Thus, some demographers now predict that the second child policy may lead to only 2-4 million additional people in China each year for the next 10 years.

China's accelerated increase in urban population, relative to that in the rural countryside, is and will continue have an impact on food consumption. China's urbanization rate reached $57 \%$ in 2016 , and may increase to $65 \%$ by 2025 and $80 \%$ by 2050 . Who will produce the food in the countryside given these statistics? Even though there is a leveling off in China's population, with an ever-aging population and a lower demand for food by city dwellers compared to people in the countryside, there still needs to be an educated workforce devoted to producing, processing, packaging and distributing the food safely and affordably.

With China's population approaching its peak, grain consumption is expected to decrease starting this year. According to consumption patterns of grain in China, direct grain consumption accounts for only $30 \%$, the remainder of which is found in processed grain products for food and feed. Thus, the general consumption of food products has been stable for the past 3 years. In contrast, the total production of meat, milk, and beer has gone down to 4, 6 and 7\%, respectively from 2014 to $2016 .^{8}$ This suggests that total food consumption in China has reached or is approaching a maximum. These results can be explained by the fact that the Chinese people primarily consume a vegetarian diet of $400 \mathrm{~kg}$ of food consumed per capita. Based on the annual grain output in China, food consumption per capita reached $350 \mathrm{~kg}$ in $2004,400 \mathrm{~kg}$ in 2010 and $450 \mathrm{~kg}$ in 2015 . Believe it or not, China now has the highest number of obese people in the world. In the coming decade, annual grain production should stabilize at about 
600 million tons which will allow food consumption per capita above $430 \mathrm{~kg}$.

Finally, China is wasting food. About one-sixth of the total grain produced in China is wasted annually in the production, processing and transportation of food because of poor equipment and logistical issues. The amount of the "wasted grain" is equivalent to about one-sixth of the total grain produced in China. In addition, there is also considerable waste in the form of consumer left-overs and waste from outdated food removed from supermarkets. Although there is no reliable data on food waste yet available in China to analyze this trend, it is anticipated that future improvements to China's industrialization and consumer behavior, will result in a reduction of food waste.

In summary, China's food and agricultural system is undergoing a historic transformation and will continue to do so into the foreseeable future. In recent years, there has been no space available in some state-owned grain reserves and some difficulty in selling grains. The price of corn in 2017 fell to about 35\% of its price in 2015. China plans to reduce 3.3 million hectares of farmland for planting maize ( $3 \%$ of countrywide farmland) from 2016 to 2020 reducing environmental pollution. This action also reflects China's government new confidence in its national food security. Newly accepted imports, such as rice from USA, will relieve some pressure for domestic production. China has successfully defended and overcome the shocks of floods with "grain" being its "levee system" and, although the water level is expected to remain high over the next decade, it is expected to decline thereafter. Thus, we are cautiously optimistic about the future of China's food security, but China must place close attention to the coordinated sustainable development of its people, resources and environment.

\section{ADDITIONAL INFORMATION}

Competing interests: The authors declare no competing financial interests.

Publisher's note: Springer Nature remains neutral with regard to jurisdictional claims in published maps and institutional affiliations.
Kai Cui ${ }^{1,2}$ and Sharon P. Shoemaker ${ }^{1}$

${ }^{1}$ California Institute of Food and Agricultural Research, University of California Davis, Davis, CA, USA and ${ }^{2}$ Antai College of Economics and Management, Shanghai Jiao Tong University, Shanghai Shi, China Correspondence: Kai Cui (kaicui@sjtu.edu.cn)

\section{REFERENCES}

1. Brown L. R. Who will Feed China? Wake-up Call for a Small Planet? The WorldWatch Environmental Alert Series (W. W. Norton \& Company, New York, USA, 1995).

2. China Ministry of Agriculture. China Agricultural Yearbooks (China Agriculture Press, Beijing, China, 1982-2017).

3. Carter, C. A., Zhong, F. \& Zhu, F. Advances in Chinese agriculture and its global implications. Appl. Econ. Perspect. Policy 34, 1-36 (2012).

4. China Ministry of Industry and Information Technology. China Food Industry Annual Reports (China light Industry Presshnology, Beijing, China, 2011-2016).

5. China National Statistics Bureau. China Population \& Employment Statistic Yearbooks (China Statistics Press, Beijing, China, 2000-2016).

6. United Nations Department of Economic and Social Affairs. The 2017 Revision of World Population Prospects (The Economic Times, 2017).

7. Ling S. China fall into low - fertility trap. Southern Weekend (Southern Media Group, Guangzhou, China, 2011).

8. China National Statistics Bureau. China Statistical Yearbooks (China Statistics Press, Beijing, China, 2011-2016).

(c) (i) Open Access This article is licensed under a Creative Commons Attribution 4.0 International License, which permits use, sharing, adaptation, distribution and reproduction in any medium or format, as long as you give appropriate credit to the original author(s) and the source, provide a link to the Creative Commons license, and indicate if changes were made. The images or other third party material in this article are included in the article's Creative Commons license, unless indicated otherwise in a credit line to the material. If material is not included in the article's Creative Commons license and your intended use is not permitted by statutory regulation or exceeds the permitted use, you will need to obtain permission directly from the copyright holder. To view a copy of this license, visit http://creativecommons. org/licenses/by/4.0/.

(c) The Author(s) 2018 